\title{
Pengaruh Ukuran Perusahaan, Umur Perusahaan, dan Investment Account Holder terhadap Pengungkapan Islamic Corporate Social Responsibility (Studi kasus pada Bank Umum Syariah yang terdaftar di Otoritas Jasa Keuangan (OJK) Tahun 2016-2019)
}

\author{
Velly Vionita $^{1}$, Kurnia ${ }^{2}$, Febrial Pratama ${ }^{3}$ \\ 1,2,3 Universitas Telkom, Fakultas Ekonomi dan Bisnis \\ vellyvionita@student.telkomuniversity.ac.id,kurnia_m2@yahoo.com, \\ dr.febytama@gmail.com
}

\begin{abstract}
Islamic Corporate Social Responsibility is a reporting of corporate social responsibility using sharia principles. Disclosure of social responsibility must be appropriate based on the values of the concept of Maqashid Shari'ah. For sharia-based companies, use Islamic Social Reporting in reporting corporate social responsibility. The entire implementation of social responsibility that has been carried out by the company will announce it to the public through social disclosure in the annual report issued by the company. This study aimed to determine the effect of company size, company age and Investment Account Holder on Islamic Corporate Social Responsibility disclosure. The population in this study is Sharia Commercial Banks registered with the Otoritas Jasa Keuangan using purposive sampling technique. This analysis techniques in this study is panel data regression. The test result of this study indicated that company size, company age and Investment Account Holder intensity simultaneousy influenced Islamic Corporate Social Responsibility disclosure. Partially, company size intensity positively affected Islamic Corporate Social Responsibility disclosure, while company age and Investment Account Holder did not affect Islamic Corporate Social Responsibility disclosure.
\end{abstract}

Keywords: company size, company age, investment account holder, islamic corporate social responsibility disclosure.

\begin{abstract}
ABSTRAK
Islamic Corporate Social Responsibility adalah pelaporan tanggung jawab sosial perusahaan dengan prinsip syariah. Pengungkapan tanggung jawab sosial harus sesuai berdasarkan nilai-nilai konsep Maqashid Syari'ah. Untuk perusahaan yang berbasis syariah, menggunakan Islamic Social Reporting dalam melakukan pelaporan tanggung jawab sosial perusahaan. Seluruh pelaksanaan tanggung jawab sosial yang telah dilaksanakan oleh perusahaan akan mengumumkannya kepada publik melalui pengungkapan sosial dalam laporan tahunan yang dikeluarkan oleh perusahaan. Penelitian ini bertujuan untuk mengetahui pengaruh ukuran perusahaan, umur perusahaan dan investment account holder terhadap pengungkapan islamic corporate social responsibility. Populasi dalam penelitian ini yaitu bank umum syariah yang terdaftar di Otoritas Jasa Keuangan dengan menggunakan teknik purposive sampling. Teknik analisis dalam penelitian ini adalah regresi data panel. Hasil pengujian penelitian ini menunjukkan bahwa ukuran perusahaan, umur perusahaan dan investment account holder berpengaruh secara simultan terhadap pengungkapan islamic corporate social responsibility. Secara parsial, ukuran perusahaan berpengaruh secara positif terhadap pengungkapan islamic corporate social responsibility, sedangkan umur perusahaan dan investment account holder tidak berpengaruh pada pengungkapan islamic corporate social responsibility.
\end{abstract}

Kata kunci: ukuran perusahaan, umur perusahaan, investment account holder, pengungkapan islamic corporate social responsibility. 


\section{A. PENDAHULUAN}

Menurut Undang-undang No 21 Tahun 2008 tentang Perbankan Syariah, mendefinisikan Bank Syariah adalah bank yang menjalankan kegiatan usaha berdasarkan prinsip syariah, atau prinsip hukum yang diatur dalam fatwa Majelis Ulama Indonesia (MUI) seperti prinsip keadilan dan keseimbangan (' $a d l$ wa tawazun), kemaslahatan (maslahah), universalisme (alamiyah), serta tidak mengandung gharar, maysir, riba, zalim dan obyek yang haram (Otoritas Jasa Keuangan 2017).

Perbankan di Indonesia berkembang karena keberadaan bank syariah yang menyediakan produk keuangan dan investasi dengan metode yang berbeda dari bank konvensional yang telah beroperasi sejak lama. Meskipun masih tergolong pendatang baru, perbankan syariah telah berkembang pesat di Indonesia. Hal ini dikarenakan status Indonesia sebagai negara penduduk muslim terbanyak di dunia, sehingga perbankan yang menggunakan hukum dan prinsip syariah lebih diminati oleh masyarakat, bahkan beberapa tahun belakangan ini bank konvensional di Indonesia turut mendirikan institusi syariah atau unit usaha syariah sendiri yang membuat lebih banyak masyarakat tertarik dengan keunggulan bank syariah (Marimin and Romdhoni, 2017)
Bank syariah sebagai institusi yang melaksanakan aktivitas operasionalnya menjunjung besar nilai-nilai Islam, dituntut tidak hanya fokus mencari keuntungan tetapi juga dituntut untuk memberikan tanggung jawab sosial kepada masyarakat atau biasa disebut dengan Corporate Social Responsibility (CSR) (Muslihati et al, 2018). Corporate Social Responsibility (CSR) tidak hanya dilakukan oleh perbankan konvensional tetapi juga dilakukan oleh perbankan syariah. Menurut Anggraini dan Kartika (2019) aktivitas-aktivitas tanggung jawab sosial perusahaan yang berdasarkan nilainilai Islam disebut dengan Islamic Corporate Social Responsibility (ICSR).

Bank syariah wajib mengungkapkan secara detail mengenai sistem produknya serta setiap produk yang dikeluarkan oleh bank wajib halal. Akad-akad yang diterapkan dalam setiap transaksi di bank syariah menuntun manusia untuk saling menghargai serta melindungi amanah yang diberikan. Oleh sebab itu, bank syariah harus mengembangkan penggunaan konsep Maqashid Syari'ah sebagai sandaran utama dalam setiap pengembangan operasional dan produkproduk yang terdapat di bank syariah (Febriadi, 2017).

Implementasi Maqashid Syari'ah pada program CSR di perbankan syariah terletak pada sejauh mana program CSR 
direalisasikan pada kegiatan operasional perbankan syariah. Program CSR merupakan bentuk tanggungjawab sosial untuk setiap entitas, baik yang bergerak di sektor manufaktur/industri, ataupun di sektor perdagangan, serta jasa terhadap lingkungan. Dalam implementasi, bentuk tanggung jawab sosial dari Islamic Corporate Social Responsibility (ICSR) merujuk pada bentuk pengelolaan Lembaga Keuangan Islam (Islamic Financial Institutions) (Muchlis and Sukirman, 2016).

Terdapat banyak faktor yang mempengaruhi pengungkapan Corporate Social Responsibility seperti ukuran perusahaan, umur perusahaan dan Investment Account Holder (IAH). Faktor pertama yang mempengaruhi pengungkapan CSR adalah ukuran perusahaan. Menurut (Rahayu and Budi S., 2018) ukuran perusahaan adalah tingkat identifikasi besar atau kecilnya suatu perusahaan. Perusahaan yang besar melakukan lebih banyak kegiatan dan memiliki dampak yang lebih besar terhadap masyarakat, mempunyai shareholder yang lebih banyak, dan mendapat lebih banyak perhatian dari kalangan publik sehingga perusahaan besar cenderung mendapat tekanan yang lebih besar untuk mengungkapkan tanggung jawab sosialnya.
Faktor kedua yang mempengaruhi pengungkapan Corporate Social Responsibility (CSR) adalah umur perusahaan. Umur perusahaan menunjukkan lamanya periode suatu perusahaan tersebut sudah ada dan telah beroperasi pada suatu industri. Perusahaan yang mempunyai umur lebih tua diasumsikan akan memberikan pengungkapan informasi yang lebih banyak dalam annual reportnya karena perusahaan yang berusia tua akan lebih mengetahui pentingnya melaksanakan tanggung jawab sosial daripada perusahaan yang berusia lebih muda atau baru saja berdiri dan beroperasi (Arianugrahini and Firmansyah, 2020)

Faktor ketiga yang mempengaruhi pengungkapan Corporate Social Responsibility (CSR) adalah Investment Account Holder (IAH). Investment Account Holder adalah bentuk kepemilikan pada perbankan syariah yang sumbernya berasal dari nasabah. Kebanyakan Investor Islam lebih memilih untuk menginvestasikan uangnya sebagai Investment Account Holder daripada sebagai pemegang saham. Disisi lain, Investment Account Holder tidak memperoleh hak suara resmi dalam pengambilan keputusan yang dilakukan oleh manajemen melalui pemegang saham, namun keuntungan pemegang saham ditentukan melalui keuntungan 
yang diperoleh dari pengelolaan dana Investment Account Holder (IAH) (Farook et al, 2011).

Berdasarkan uraian latar belakang dan faktor-faktor yang mempengaruhi pengungkapan Corporate Social Responsibility (CSR), maka penelitian ini menarik peneliti untuk melakukan penelitian kembali tentang Pengaruh Ukuran Perusahaan, Umur Perusahaan, dan Investment Account Holder Terhadap Pengungkapan Islamic Corporate Social Responsibility (Studi kasus pada Bank Umum Syariah yang terdaftar di Otoritas Jasa Keuangan (OJK) tahun 2016-2019).

\section{B. TINJAUAN PUSTAKA}

\section{Teori Stakeholder}

Menurut Freeman (1984) teori stakeholder adalah keberadaan suatu perusahaan sangat dipengaruhi oleh kelompok atau individu yang memiliki hubungan dengan perusahaan tersebut. Teori stakeholder menjelaskan bahwa perusahaan bukan entitas yang hanya beroperasi untuk kepentingannya sendiri, namun harus memberikan manfaat juga kepada stakeholder seperti pemegang saham, kreditor, konsumen, supplier, pemerintah, masyarakat, analis dan pihak lain. Kelompok stakeholder menjadi pertimbangan utama perusahaan dalam mengungkapkan atau tidak mengungkapkan suatu informasi dalam laporan tahunan perusahaan (Pratama et al, 2018).

\section{Teori Legitimasi}

Teori Legitimasi menurut Deegan (2002) adalah perusahaan akan bereaksi sesuai dengan ekspektasi masyarakat dan lingkungan di sekitar tempat perusahaan tersebut beroperasi. Teori ini fokus pada strategi-strategi perusahaan dalam mengelola berbagai ekspektasi yang akan berdampak pada perusahaan agar mendapatkan status yang legal. Salah satu alat untuk mendapatkan status tersebut adalah dengan melakukan aktivitas tanggung jawab sosial dan lingkungan. Selain itu, risiko penurunan reputasi juga dapat diminimalisir dengan patuh pada regulasi dan norma sosial serta melakukan kegiatan-kegiatan yang melibatkan masyarakat (Anggraini and Kartika, 2019).

\section{Corporate Social Responsibility (CSR)}

Tanggung jawab sosial atau Corporate Social Responsibility adalah perusahaan memiliki kewajiban yang tidak hanya dalam hal keuangan saja tetapi juga terhadap masalah sosial dan lingkungan sekitar perusahaan agar perusahaan dapat tumbuh secara berkelanjutan (Tampubolon and Siregar, 2019). Dengan melakukan CSR perusahaan dapat membentuk citra positif di mata masyarakat dan juga investor 
perusahaan, tidak hanya mendapatkan kepercayaan dari investor untuk berinvestasi tetapi perusahaan juga memiliki hubungan yang baik dengan masyarakat sekitar (Dewi and Sedana, 2019).

\section{Pengungkapan Islamic Corporate Social Responsibility (ICSR)}

Menurut Khursid et al (2014) Islamic Corporate Social Responsibility (ICSR) adalah konsep tanggung jawab sosial perusahaan berbasis syariah yang berukuran ekonomi Islam, legal Islam, etika Islam, dan filantropi Islam bersumber nilai-nilai keislaman yang terdapat pada Al-Qur'an dan Hadits. Pengungkapan Islamic Corporate Social Responsibility (ICSR) oleh lembaga syariah memiliki perbedaan konsep dengan pengungkapan CSR lembaga konvensional, demikian pula konsep pengungkapan dalam lembaga keuangan syariah. Konsep pengungkapan ICSR pada lembaga keuangan syariah wajib mencakup seluruh aktivitas yang ditunjukkan kepada objek ICSR ialah alam, direct stakeholder, dan indirect stakeholder (Hendratmoko and Muid, 2017).

\section{Islamic Social Reporting (ISR)}

Terkait adanya kebutuhan mengenai pengungkapan Corporate Social Responsibility (CSR) di perbankan syariah, maka perlu adanya standar khusus untuk pelaporan tanggung jawab sosial yang sesuai dengan prinsip Islam yang disebut dengan Islamic Social Reporting (ISR) (Othman and Thani, 2010). Islamic Social Reporting dikemukakan pertama kali dalam penelitian Haniffa (2002) dan hanya berisikan lima tema, yaitu pembiayaan dan investasi, produk dan jasa, karyawan, masyarakat, dan lingkungan. Setelah itu, Othman dan Thani (2010) juga menambahkan satu tema pengungkapan ialah tata kelola perusahaan. Untuk mendapatkan nilai Islamic Corporate Social Responsibility (ICSR), jumlah skor disclosure yang dipenuhi dibandingkan dengan jumlah skor maksimum. Penilaian pada masing-masing item pengungkapan menggunakan indeks Islamic Social Reporting (ISR) yang terdiri dari 50 item pernyataan yang digunakan oleh Fauziah dan Yudho J (2013). Menggunakan metode nilai (skor), nilai 0 untuk item yang tidak diungkapkan dan nilai 1 untuk item yang diungkapkan. Maka, pengungkapan Islamic Corporate Social Responsibility (ICSR) dapat dihitung menggunakan rumus sebagai berikut:

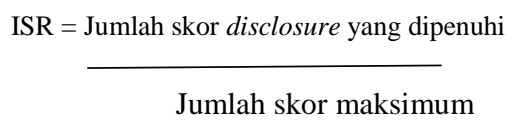




\section{Ukuran Perusahaan}

Menurut Hendratmoko dan Muid (2017) ukuran perusahaan merupakan suatu skala yang dapat mengklasifikan perusahaan menjadi perusahaan besar dan kecil menurut berbagai metode, antara lain: total aktiva atau total aset perusahaan, rata-rata tingkat penjualan serta jumlah penjualan. Semakin besar ukuran suatu perusahaan maka semakin banyak kegiatan yang dilakukan dan memberikan dampak yang lebih besar terhadap masyarakat, tidak hanya itu perusahaan yang besar memiliki kemampuan merekrut karyawan yang ahli, dan terdapatnya tuntutan dari shareholder serta analis, hal ini menimbulkan perusahaan yang berukuran besar melakukan pengungkapan Corporate Social Responsibility (CSR) yang lebih luas daripada perusahaan yang berukuran kecil (Mutia et al, 2011)

Perusahaan yang berukuran besar atau kecil dapat dilihat dari nilai total aset yang dimiliki perusahaan tersebut. Nilai total aset perusahaan dapat diperoleh dari laporan posisi keuangan pada akhir periode perusahaan dalam laporan tahunan (annual report) perusahaan dan dapat dilihat pada ba $\begin{gathered}\text { Ukuran Bank=logaritma natural } \\ \text { Total Aset }\end{gathered}$,ngan umur perusahaan adalah laporan keuangan per and Baiquni, 2019). Ukuran perusahaan dalam penelitian ini diukur menggunakan logaritma natural dari total aset perusahaan. Rumus perhitungan ukuran perusahaan adalah sebagai berikut:

\section{(2.2)}

\section{Umur rerusahaan}

Umur perusahaan dapat mencerminkan seberapa besar perusahaan tersebut. Seberapa besar suatu perusahaan dapat digambarkan dalam kedewasaan perusahaan. Kedewasaan perusahaan akan membuat perusahaan yang bersangkutan memahami apa yang diinginkan oleh stakeholder serta shareholdernya. Perusahaan yang telah lama berdiri tentunya akan mendapat perhatian lebih dari masyarakat luas. Dengan demikian, tentunya perusahaan yang telah lama berdiri akan senantiasa menjaga stabilitas dan citra perusahaan. Untuk menjaga stabilitas serta citra, perusahaan akan berupaya mempertahankan dan meningkatkan kualitas pengungkapan sosialnya (Prasetyoningrum, 2019). Umur perusahaan dapat dihitung dari sejak berdirinya perusahaan tersebut sampai akhir tahun annual report. Rumus hi berikut: 


\section{Investment Account Holder}

Investment Account Holder (IAH) merupakan struktur kepemilikan pada perbankan yang sumbernya berasal dari dana nasabah atau diproxykan dengan dana syirkah temporer (Farook et al, 2011). Dengan banyaknya jumlah IAH yang terdapat di perbankan, maka semakin banyak tingkat keyakinan masyarakat terhadap perbankan sebab jumlah IAH yang besar serta semakin banyak pula nasabah yang menggunakan jasa IAH tersebut (Setyawan, 2017). Rumus perhitungan Investment Account Holder adalah sebagai berikut:

nbilan keputusan. Selain itu, rusanaan besar cenderung memiliki public demand terhadap informasi yang lebih tinggi dibanding perusahaan yang berukuran lebih kecil (Aini et al. 2017). Besar atau kecilnya perusahaan dapat diukur dengan logaritma natural dari total aset yang dimiliki perusahaan.

Pada penelitian sebelumnya yang dilakukan oleh Masrurroh dan Mulazid (2017) menyatakan bahwa ukuran perusahaan yang diproksikan menggunakan logaritma natural dari total aset perusahaan berpengaruh positif terhadap pengungkapan Corporate Social Responsibility (CSR) dimana semakin besar ukuran perusahaan maka semakin \begin{tabular}{|c|} 
IAH $=$ jumlah total dana syirkah temporer \\
modal disetor penuh (fully paid-up capital)
\end{tabular} pengungkapan informasi sahaan yang harus dilakukan. Perusahaan yang berukuran besar

\section{Kerangka Pemikiran}

\section{a. Pengaruh Ukuran Perusahaan} berpengaruh terhadap

\section{Pengungkapan Islamic}

Corporate Social Responsibility (ICSR)

Ukuran perusahaan merupakan ukuran besar atau kecilnya perusahaan tersebut, hal ini dapat dilihat dari seberapa besar aset yang dimiliki perusahaan dalam laporan tahunan yang dibuat. Perusahaan yang besar memiliki banyak informasi untuk investor yang dapat membantu memiliki aktiva yang besar, penjualan besar, keahlian karyawan yang baik dan jenis produk yang banyak, sehingga perusahaan yang berukuran besar mengungkapkan tanggung jawab sosialnya lebih banyak daripada perusahaan yang berukuran kecil.

H1: Ukuran perusahaan memiliki pengaruh positif secara parsial terhadap pengungkapan Islamic Corporate Social Responsibility (ICSR).

\section{b. Pengaruh Umur Perusahaan berpengaruh terhadap} Pengungkapan Islamic 
Corporate Social Responsibility (ICSR)

Menurut Raditya (2012) perusahaan dengan umur yang lebih muda akan melakukan penyebaran informasi yang lebih banyak dibandingkan dengan umur perusahaan yang lebih tua dengan tujuan untuk mengurangi ketidakpastian risiko operasi serta untuk meningkatkan kepercayaan diri investor terhadap posisi mereka, tetapi perusahaan dengan umur yang lebih tua kemungkinan besar akan mengungkapkan informasi lebih banyak dalam laporan tahunan dibandingkan dengan perusahaan yang umurnya lebih muda (Lestari, 2016).

Berdasarkan teori stakeholders, pengungkapan sosial perusahaan dianggap berperan sebagai media komunikasi antara perusahaan dengan stakeholders. Dalam rangka memberikan feedback kepada para stakeholdernya, perusahaan akan menerbitkan laporan tanggung jawab sosialnya secara berkelanjutan setiap tahunnya. Perusahaan yang telah lama berdiri diharapkan mengetahui apa keinginan stakeholdernya dan memenuhi kebutuhan stakeholdernya dengan cara meningkatkan kualitas pengungkapan tanggung jawab sosialnya (Widiyanti and Hasanah, 2018). Hasil penelitian Pare et al (2017) menunjukkan bahwa variabel umur perusahaan berpengaruh positif terhadap Corporate Social Responsibility (CSR).

H2: Umur perusahaan memiliki pengaruh positif secara parsial terhadap pengungkapan Islamic Corporate Social Responsibility (ICSR).

\section{c. Pengaruh Investment Account}

Holder berpengaruh terhadap

Pengungkapan Islamic

Corporate Social Responsibility

(ICSR)

Investor Islam lebih cenderung berinvestasi dana sebagai Investment Account Holder (IAH) daripada sebagai pemegang saham karena investor lebih tertarik pada layanan yang ditawarkan bank syariah dan rekening investasi dengan bank syariah pada umumnya lebih mudah diakses daripada saham syariah bank (Farook et al, 2011).

Jika IAH lebih menarik daripada kepemilikan saham pada perbankan syariah, kemudian pengaruh IAH akan ditunjukkan kepada ketaatan perbankan syariah pada prinsip dan hukum Islam sehingga akan membuat perbankan lebih memberikan pengungkapannya (Zanjabil and Adityawarman, 2015). Hasil penelitian sebelumnya dari Mais dan Lufian (2018) menunjukkan bahwa variabel IAH memiliki hubungan positif terhadap tingkat pengungkapan CSR yang 
menggunakan indeks Islamic Social dengan kriteria perusahaan sebagai Reporting (ISR).

berikut:

H3: Investment Account Holder

memiliki pengaruh positif secara parsial terhadap pengungkapan Islamic

1. Bank Umum Syariah yang terdaftar di Corporate Social Responsibility (ICSR).

Otoritas Jasa Keuangan (OJK) tahun 2016-2019.

2. Bank Umum Syariah yang terdaftar di

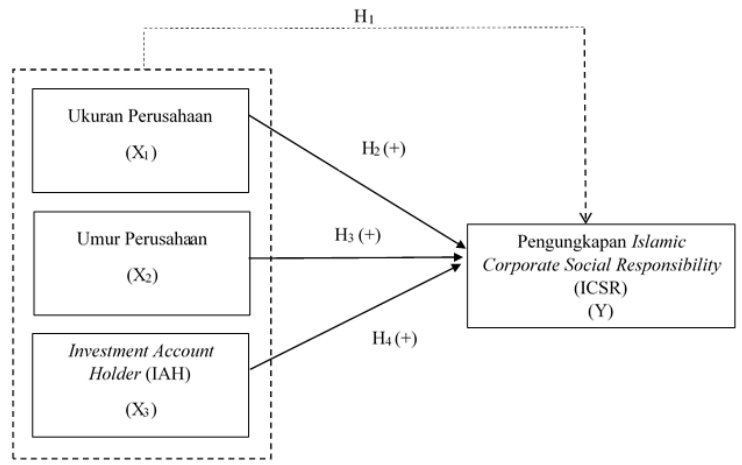

Keuangan (OJK) yang nenerbitkan laporan ahun 2016-2019.

Syariah yang memiliki data berdasarkan diteliti selama periode

Berdasarkan kriteria tersebut, jumlah

Gambar 1 Kerangka Pemikiran

\section{METODE PENELITIAN}

Metode yang digunakan dalam penelitian ini adalah metode penelitian kuantitatif. Populasi dalam penelitian ini yaitu Bank Umum Syariah (BUS) yang terdaftar di Otoritas Jasa Keuangan (OJK) tahun 2016-2019. Teknik pengambilan sampel yang digunakan yaitu menggunakan teknik purposive sampling sampel yang diteliti sebanyak 13 bank dengan periode empat tahun penelitian, sehingga data yang digunakan dalam penelitian ini berjumlah 52 sampel. Teknik analisis data dalam penelitian ini adalah regresi data panel yang diolah menggunakan aplikasi Eviews 11. Berikut merupakan persamaan analisis regresi data panel:

$$
\mathrm{ICSR}=\alpha+\beta_{1} \mathrm{X}_{1}+\beta_{2} \mathrm{X}_{2}+\beta_{3} \mathrm{X}_{3}+\mathrm{e}
$$

Keterangan:

$$
\begin{array}{ll}
\text { ICSR } & =\text { Pengungkapan Islamic Corporate Social Responsibility (ICSR) } \\
\alpha & =\text { Konstanta } \\
\mathrm{X}_{1} & =\text { Ukuran Perusahaan } \\
\mathrm{X}_{2} & =\text { Umur Perusahaan } \\
\mathrm{X}_{3} & =\text { Investment Account Holder } \\
\beta_{(1 \ldots 3)} & =\text { Koefesien Regresi masing-masing variabel independen } \\
\mathrm{e} & =\text { error/kesalahan }
\end{array}
$$




\section{HASIL PEMBAHASAN}

\section{Analisis Statistik Deskriptif}

Tabel 1

Hasil Pengujian Statistik Deskriptif

\begin{tabular}{lcccc}
\hline \hline & ICSR & SIZE & AGE & IAH \\
\hline \hline Mean & 0.622758 & 30.07842 & 9.730769 & 10.56996 \\
Median & 0.639400 & 29.79388 & 8.000000 & 5.951870 \\
Maximum & 0.770200 & 32.35212 & 27.00000 & 41.83844 \\
Minimum & 0.440000 & 27.21840 & 0.000000 & 0.000000 \\
Std. Dev. & 0.083851 & 1.274667 & 6.278239 & 10.60435
\end{tabular}

Pada tabel 1 hasil pengujian statistik deskriptif untuk masing-masing variabel sebagai berikut:

a. Variabel dependen pengungkapan Islamic Corporate Social Responsibility diperoleh nilai mean sebesar 0,622758, nilai standar deviasi sebesar 0,083851, nilai maksimum sebesar 0,770200 dan nilai minimum sebesar 0,440000 .

b. Variabel independen ukuran perusahaan memiliki mean sebesar 30,07842, nilai standar deviasi sebesar 1,274667, nilai maksimum sebesar 32,35212 dan nilai minimum sebesar 27,21840.

c. Nilai rata-rata variabel independen umur perusahaan sebesar 9,730769 dan nilai standar deviasi sebesar 6,278239, nilai maksimum sebesar 27,00000 dan nilai minimum sebesar 0,00000 . d. Nilai rata-rata variabel independen Investment Account Holder sebesar 10,56996, nilai standar deviasi sebesar 10,60435, nilai maksimum 41,83844 dan nilai minimum sebesar 0,000000 .

\section{Uji Asumsi Klasik}

Uji asumsi klasik yang digunakan dalam regresi linier dengan pendekatan Ordinary Least Square (OLS) antara lain uji normalitas, linieritas, multikolinearitas, heteroskedastisitas, dan autokorelasi. Namun, tidak semua uji asumsi klasik harus dilakukan karena model diasumsikan sudah linier maka tidak perlu uji linieritas, pada syarat Best Linear Unbiased Estimator uji normalitas tidak perlu dilakukan, dan uji autokorelasi hanya terjadi pada data time series saja. Sehingga uji asumsi klasik yang digunakan pada penelitian ini yaitu hanya uji multikolinearitas dan uji heteroskedastisitas. 


\section{a. Uji Multikolinearitas}

\section{Tabel 2}

\section{Hasil Uji Multikolinearitas}

\begin{tabular}{cccc} 
& SIZE & AGE & IAH \\
\hline \hline SIZE & 1.000000 & 0.461720 & 0.743104 \\
AGE & 0.461720 & 1.000000 & 0.702468 \\
IAH & 0.743104 & 0.702468 & 1.000000
\end{tabular}

Diketahui pada tabel 2 menunjukkan bahwa nilai koefisien korelasi antar variabel independen $<0,80$ yang artinya tidak terjadi multikolinearitas.

\section{b. Uji heterokedastisitas}

Tabel 3

\section{Hasil Uji Heteroskedastisitas}

Heteroskedasticity Test: White

Null hypothesis: Homoskedasticity

\begin{tabular}{llll}
\hline \hline F-statistic & 2.256598 & Prob. F $(3,48)$ & 0.0938 \\
Obs $*$-squared & 6.427434 & Prob. Chi-Square(3) & $\mathbf{0 . 0 9 2 6}$ \\
Scaled explained SS & 6.145798 & Prob. Chi-Square(3) & 0.1047 \\
\hline \hline
\end{tabular}

Hasil uji heteroskedastisitas dengan uji white pada tabel 3 menunjukkan bahwa nilai probabilitas chi-square sebesar 0,0926 dimana nilai tersebut >0,05. Sehingga dapat disimpulkan bahwa sebaran data pada penelitian ini bersifat homokedastisitas atau tidak terdapat gejala heterokedastisitas.

\section{Pemilihan Model Regresi Data Panel}

\section{a. Uji Chow}

Tabel 4

Hasil Uji Chow

\begin{tabular}{|c|c|c|c|}
\hline Effects Test & Statistic & d.f. & Prob. \\
\hline Cross-section F & 5.098907 & $(12,36)$ & 0.0001 \\
\hline Cross-section Chi-square & 51.642072 & 12 & 0.0000 \\
\hline
\end{tabular}

Diketahui pada tabel 4 nilai probabilitas chi-square yang diperoleh adalah 0.000000 lebih kecil dari 0,05 artinya H0 ditolak maka model yang digunakan adalah fixed effect model dibandingkan dengan common effect model. Selanjutnya dilakukan pengujian untuk memilih model fixed effect model atau random effect model. 


\section{b. Uji Hausman}

\section{Tabel 5}

\section{Hasil Uji Hausman}

Correlated Random Effects - Hausman Test

Equation: Untitled

Test cross-section random effects

\begin{tabular}{llrl}
\hline \hline Test Summary & \multicolumn{1}{c}{ Chi-Sq. } & & \\
\hline \hline Cross-section random & Statistic & Chi-Sq. d.f. & Prob. \\
\hline
\end{tabular}

Berdasarkan hasil uji hausman pada tabel 5 dapat diketahui bahwa nilai cross section random adalah sebesar 0.3885 dimana nilai tersebut $>0,05$ sehingga dapat disimpulkan bahwa model yang digunakan berdasarkan hasil uji hausman adalah random effect model. Selanjutnya dilakukan pengujian untuk memilih model common effect model atau random effect model.

c. Uji Lagrange Multiplier

\section{Tabel 6}

\section{Hasil Uji Lagrange Multiplier}

Lagrange Multiplier Tests for Random Effects

Null hypotheses: No effects

Alternative hypotheses: Two-sided (Breusch-Pagan) and one-

sided

(all others) alternatives

\begin{tabular}{llll}
\hline \hline & \multicolumn{3}{c}{ Test Hypothesis } \\
& $\begin{array}{c}\text { Cross- } \\
\text { section }\end{array}$ & Time & Both \\
\hline \hline Breusch-Pagan & $\begin{array}{llll}16.58038 \\
(\mathbf{0 . 0 0 0 0 )}\end{array}$ & $\begin{array}{l}0.130096 \\
(0.7183)\end{array}$ & $\begin{array}{l}16.71047 \\
(0.0000)\end{array}$ \\
\hline \hline
\end{tabular}

Diketahui pada tabel 6 hasil uji lagrange multiplier menunjukkan bahwa nilai probabilitas Breush-Pagan cross section adalah 0,000000 < 0,05 maka $\mathrm{H} 0$ diterima artinya model yang tepat adalah random effect model.

\section{Persamaan Regresi Data Panel}

\section{Tabel 7}

\section{Hasil Uji Random Effect Model}

Dependent Variable: ICSR

Method: Panel EGLS (Cross-section random effects)

Date: 01/15/21 Time: 23:11

Sample: 20162019 
Periods included: 4

Cross-sections included: 13

Total panel (balanced) observations: 52

Swamy and Arora estimator of component variances

\begin{tabular}{|c|c|c|c|c|}
\hline Variable & Coefficient & Std. Error & $t$-Statistic & Prob. \\
\hline $\mathrm{C}$ & -1.113976 & 0.383530 & -2.904539 & 0.0055 \\
\hline$S I Z E$ & 0.057364 & 0.013152 & 4.361548 & 0.0001 \\
\hline$A G E$ & 0.004042 & 0.002340 & 1.727338 & 0.0905 \\
\hline$I A H$ & -0.002650 & 0.001680 & -1.577826 & 0.1212 \\
\hline \multicolumn{5}{|c|}{ Effects Specification } \\
\hline & & & S.D. & Rho \\
\hline Cross-section randon & & & 0.042440 & 0.5756 \\
\hline Idiosyncratic random & & & 0.036439 & 0.4244 \\
\hline \multicolumn{5}{|c|}{ Weighted Statistics } \\
\hline Root MSE & 0.035017 & \multirow{5}{*}{\multicolumn{2}{|c|}{$\begin{array}{l}R \text {-squared } \\
\text { Adjusted } R \text {-squared } \\
\text { S.E. of regression } \\
\text { F-statistic } \\
\text { Prob(F-statistic) }\end{array}$}} & 0.403367 \\
\hline Mean dependent var & 0.245669 & & & 0.366078 \\
\hline S.D. dependent var & 0.045776 & & & 0.036447 \\
\hline Sum squared resid & 0.063761 & & & 10.81717 \\
\hline Durbin-Watson stat & 1.872756 & & & 0.000015 \\
\hline \multicolumn{5}{|c|}{ Unweighted Statistics } \\
\hline$R$-squared & 0.634291 & \multirow{2}{*}{\multicolumn{2}{|c|}{$\begin{array}{l}\text { Mean dependent var } \\
\text { Durbin-Watson stat }\end{array}$}} & 0.622758 \\
\hline Sum squared resid & 0.131136 & & & 0.910572 \\
\hline
\end{tabular}

Berdasarkan tabel 7 maka diperoleh persamaan regresi data panel untuk penelitian sebagai berikut.

$$
\begin{gathered}
Y=-1,113976+0,057364\left(X_{1}\right)+ \\
0,004042\left(X_{2}\right)-0,002650\left(X_{3}\right)
\end{gathered}
$$

Hasil persamaan regresi data panel di atas dapat menjelaskan keterkaitan antara variabel independen terhadap pengungkapan Islamic Corporate Social Responsibility seperti berikut:

a. Nilai konstanta sebesar $-1,113976$ menunjukkan jika variabel ukuran perusahaan, umur perusahaan, dan
Investment Account
Holder
bernilai 1 maka nilai pengungkapan Islamic Corporate Social Responsibilitynya adalah - 1,113976 .

b. Nilai koefisien $X_{1}$ yaitu ukuran perusahaan sebesar 0,057364 bernilai positif menunjukkan bahwa jika terjadi kenaikan sebesar satu satuan terhadap ukuran perusahaan dan nilai variabel independen lain konstan, maka pengungkapan Islamic 
Corporate Social Responsibility meningkat sebesar 0,057364 .

c. Nilai koefisien $\mathrm{X}_{2}$ yaitu umur perusahaan sebesar 0,004042 bernilai positif menunjukkan bahwa jika terjadi kenaikan sebesar satu satuan terhadap umur perusahaan dan nilai variabel independen lain konstan, maka pengungkapan Islamic Corporate Social Responsibility meningkat sebesar 0,004042 .

d. Nilai koefisien $\mathrm{X}_{3}$ yaitu Investment Account Holder sebesar -0,002650 bernilai negatif menunjukkan bahwa jika terjadi kenaikan sebesar satu satuan terhadap Investment Account Holder dan nilai variabel independen lain konstan, maka pengungkapan Islamic Corporate Social Responsibility menurun sebesar 0,002650 .

\section{Koefisien Determinasi}

Berdasarkan tabel 7 diperoleh nilai Adjusted R-square sebesar 0,366078 yang artinya variabel ukuran perusahaan, umur perusahaan, dan Investment Account Holder memiliki kemampuan menjelaskan pengungkapan Islamic Corporate Social Responsibility sebesar $36,60 \%$ dan selebihnya dijelaskan oleh variabel lain di luar penelitian ini.

\section{Uji Simultan (Uji F)}

Berdasarkan pada tabel 7 diperoleh nilai probabilitas F-statistic sebesar $0,000015<0,05$ artinya variabel independen ukuran perusahaan, umur perusahaan, dan Investment Account Holder berpengaruh secara simultan terhadap variabel dependen pengungkapan Islamic Corporate Social Responsibility.

\section{Uji Parsial (Uji t)}

Berdasarkan pada tabel 7 menunjukkan hasil uji parsial untuk variabel ukuran perusahaan, umur perusahaan, dan Investment Account Holder terhadap pengungkapan Islamic Corporate Social Responsibility. Uraian penjelasan hubungan antar variabel sebagai berikut:

a. Variabel ukuran perusahaan $\left(\mathrm{X}_{1}\right)$ memiliki nilai probabilitas sebesar $0,0001<0,05$ dengan nilai koefisien sebesar 0,057364. Hal tersebut menunjukkan jika variabel ukuran perusahaan berpengaruh secara positif terhadap pengungkapan Islamic Corporate Social Responsibility.

b. Variabel umur perusahaan $\left(\mathrm{X}_{2}\right)$ memiliki nilai probabilitas sebesar 0,0905>0,05 dengan nilai koefisien sebesar 0,004042. Hal tersebut menunjukkan jika variabel umur perusahaan tidak berpengaruh terhadap 
pengungkapan Islamic Corporate

Social Responsibility.

c. Variabel Investment Account Holder $\left(\mathrm{X}_{3}\right)$ memiliki nilai probabilitas sebesar $0,1212>0,05$ dengan nilai koefisien sebesar 0,002650. Hal tersebut menunjukkan jika variabel Investment Account Holder tidak berpengaruh terhadap pengungkapan Islamic Corporate Social Responsibility.

\section{Pembahasan Hasil Penelitian}

a. Pengaruh Ukuran Perusahaan terhadap Pengungkapan Islamic Corporate Social Responsibility

Variabel ukuran perusahaan memperoleh nilai probabilitas sebesar $0,0001<0,05$ dengan nilai koefisien sebesar 0,057364. Hasil pengujian parsial tersebut menunjukkan bahwa variabel ukuran perusahaan secara parsial berpengaruh positif terhadap pengungkapan Islamic Corporate Social Responsibility sehingga $\mathrm{H}_{2}$ diterima. Hasil penelitian ini sesuai dengan hipotesis penelitian yang menyatakan bahwa ukuran perusahaan berpengaruh positif secara parsial terhadap pengungkapan Islamic Corporate Social Responsibility.
Ukuran perusahaan dapat dilihat dari total nilai aset yang dimiliki perusahaan. Berdasarkan analisis yang dilakukan, bank syariah yang memiliki ukuran perusahaan yang besar akan memiliki total aset yang besar sehingga pengungkapan tanggung jawab sosial berbasis syariah akan menjadi lebih luas dan akan semakin menarik perhatian publik dibandingkan dengan bank syariah yang memiliki ukuran perusahaan yang kecil yang harus memerlukan banyak biaya tambahan untuk pengungkapan yang lebih luas. Hasil penelitian ini sesuai dengan penelitian yang dilakukan Masrurroh dan Mulazid (2017); ukuran perusahaan berpengaruh secara positif terhadap pengungkapan Islamic Corporate Social Responsibility.

b. Pengaruh Umur Perusahaan terhadap Pengungkapan Islamic Corporate Social Responsibility

Variabel umur perusahaan memperoleh nilai probabilitas sebesar 0,0905 > 0,05 dengan nilai koefisien sebesar 0,004042. Hasil pengujian parsial tersebut menunjukkan bahwa variabel umur perusahaan tidak berpengaruh terhadap 
pengungkapan Islamic Corporate

Social Responsibility sehingga $\mathrm{H}_{3}$

ditolak. Hasil penelitian ini tidak sesuai dengan hipotesis yang menyatakan bahwa umur perusahaan berpengaruh positif secara parsial terhadap pengungkapan Islamic Corporate Social Responsibility.

Berdasarkan analisis yang dilakukan, umur perusahaan tidak berpengaruh terhadap pengungkapan Islamic Corporate Social Responsibility karena semakin lama bank berdiri bukan berarti bank akan semakin menunjukkan eksistensi dalam pengungkapan tanggung jawab sosialnya, karena bank yang berumur lebih tua mungkin lebih baik dalam memahami informasi apa saja yang diungkapkan sehingga tidak perlu mengungkapkan secara detail informasi tanggung jawab sosialnya dalam laporan tahunan dan untuk umur perusahaan yang lebih muda, pengungkapan tanggung jawab sosial sangat penting karena perusahaan yang lebih muda membangun legitimasi perusahaan kepada masyarakat, sehingga penting bagi perusahaan untuk melakukan tanggung jawab sosial yang lebih luas. Dapat dilihat bahwa umur perusahaan bukan merupakan faktor yang mempengaruhi kinerja perusahaan dalam mengungkapkan tanggung jawab sosial. Hasil penelitian ini sesuai dengan penelitian yang dilakukan Arianugrahini dan Firmansyah (2020); umur perusahaan tidak berpengaruh terhadap pengungkapan Islamic Corporate Social Responsibility.

\section{c. Pengaruh Investment Account} Holder terhadap Pengungkapan Islamic Corporate Social Responsibility

Variabel Investment Account Holder memperoleh nilai probabilitas sebesar $0,1212>0,05$ dengan nilai koefisien sebesar 0,002650 menunjukkan arah negatif. Hasil pengujian parsial tersebut menunjukkan bahwa variabel Investment Account Holder tidak berpengaruh terhadap pengungkapan Islamic Corporate Social Responsibility sehingga $\mathrm{H}_{4}$ ditolak. Hasil penelitian ini tidak sesuai dengan hipotesis yang menyatakan bahwa Investment Account Holder berpengaruh positif secara parsial terhadap pengungkapan Islamic Corporate Social Responsibility. 
Berdasarkan analisis yang dilakukan, Investment Account Holder tidak memiliki pengaruh terhadap pengungkapan Islamic Corporate Social Responsibility, karena semakin rendah tingkat Investment Account Holder maka semakin sedikit pengungkapan yang dilakukan oleh perbankan syariah. Selain itu, tidak berpengaruhnya Investment Account Holder terhadap pengungkapan Islamic Corporate Social Responsibility juga mendukung bahwa sebagian besar perbankan syariah di Indonesia masih kecil dibandingkan dengan bank konvensional, oleh karena itu perlu mempromosikan dan meningkatkan pangsa pasar dengan berbagai cara. Salah satu strategi perbankan syariah adalah meningkatkan pengungkapan Islamic Corporate Social Responsibility untuk menarik nasabah. Strategi ini sebenarnya menguntungkan perbankan syariah karena selain memenuhi kewajiban untuk melakukan pengungkapan tanggung jawab sosial perusahaan, perbankan syariah juga melakukan kegiatan promosi untuk menarik minat nasabah, bukan sebagai pemegang saham tetapi sebagai Investment Account Holder untuk menginvestasikan dananya. Namun saat ini tingkat Investment Account Holder di perbankan syariah masih rendah dan masih diperlukan banyak promosi sehingga nasabah tertarik untuk berinvestasi di perbankan syariah. Hasil penelitian ini sesuai dengan penelitian yang dilakukan Sudaryati and Eskadewi (2012); Investment Account Holder tidak berpengaruh terhadap pengungkapan Islamic Corporate Social Responsibility.

\section{E. KESIMPULAN}

Penelitian ini bertujuan untuk meneliti pengaruh antara ukuran perusahaan, umur perusahaan, Investment Account Holder, dan pengungkapan Islamic Corporate Social Responsibility pada bank umum syariah yang terdaftar di Otoritas Jasa Keuangan (OJK) periode 2016-2019 dengan jumlah sampel bank sebanyak 13 bank, dengan periode penelitian empat tahun sehingga mendapatkan jumlah sampel 52 unit sampel penelitian, maka diperoleh kesimpulan sebagai berikut.

1. Variabel independen ukuran perusahaan, umur perusahaan, dan Investment Account Holder secara 
simultan berpengaruh terhadap

variabel dependen pengungkapan

Islamic Corporate Social

Responsibility pada bank umum syariah yang terdaftar di Otoritas Jasa Keuangan (OJK) tahun 2016-2019.

2. Ukuran perusahaan secara parsial berpengaruh positif terhadap pengungkapan Islamic Corporate Social Responsibility pada bank umum syariah yang terdaftar di Otoritas Jasa Keuangan (OJK) tahun 2016-2019.

3. Umur perusahaan secara parsial tidak berpengaruh terhadap pengungkapan Islamic Corporate Social Responsibility pada bank umum syariah yang terdaftar di Otoritas Jasa Keuangan (OJK) tahun 2016-2019.

4. Investment Account Holder secara parsial tidak berpengaruh terhadap pengungkapan Islamic Corporate Social Responsibility pada bank umum syariah yang terdaftar di Otoritas Jasa Keuangan (OJK) tahun 2016-2019.

\section{DAFTAR PUSTAKA}

Aini, Nur, Yeye Susilowati, Kentris Indarti, and Ratna Fauziyyah Age. (2017). Pengaruh Umur Perusahaan, Ukuran Perusahaan, Leverage, Likuiditas, Profitabilitas Dan Kinerja Lingkungan Hidup Terhadap Pengungkapan Islamic Social
Reporting Pada Perusahaan Yang Terdaftar Di Jakarta Islamic Index (JII) TAHUN 2012 - 2015. Dinamika Akuntansi, Keuangan Dan Perbankan, 6(1): 67-82.

Anggraini, Dian Yuni., and Rayna Kartika. (2019). Analisis Kualitas Pengungkapan Islamic Corporate Social Responsibility Bank Umum Syariah Di Indonesia. Jurnal Akuntansi Dan Governance Andalas, 2(1): 18-31.

Arianugrahini, I, and E A Firmansyah. (2020). Determinan Pengungkapan Islamic Social Reporting (ISR) Pada Bank Umum Syariah Di Indonesia (Determinants of Islamic Social Reporting (ISR) Disclosure at Islamic Commercial Banks in Indonesia). AlMashrafiyah: Islamic Banking and Finance, 4(2): 88-101.

Dewi, Putu Ayu Cahya, and Ida Bagus Panji Sedana. (2019). Pengaruh Profitabilitas, Ukuran Perusahaan, Dan Leverage Terhadap Pengungkapan Corporate Social Responsibility. E-Jurnal Manajemen Universitas Udayana, 8(11): 6618.

Farook, Sayd, M. Kabir Hassan, and Roman Lanis. (2011). Determinants of Corporate Social Responsibility Disclosure: The Case of Islamic Banks. Journal of Islamic Accounting and Business Research, 2(2): 114-41.

Fauziah, Khusnul, and Prabowo Yudho J. (2013). Analisis Pengungkapan Tanggung Jawab Sosial Perbankan Syariah Di Indonesia Berdasarkan Islamic Social Reporting Indeks. Jurnal Dinamika Akuntansi, 5(1): 11.

Febriadi, Sandy Rizki. (2017). Aplikasi Maqashid Syariah Dalam Bidang Perbankan Syariah. Amwaluna: Jurnal Ekonomi Dan Keuangan Syariah, 1(2): 231-45.

Haniffa, Ros. (2002). Social Reporting 
Disclosure: An Islamic Perspective. Indonesian Management \& Accounting Research, 1(2): 128-46.

Hendratmoko, A., and D. Muid. (2017). Pengaruh Profitabilitas, Ukuran Perusahaan, Dan Pertumbuhan Penjualan Terhadap Pengungkapan Icsr Lembaga Keuangan Syariah Di Indonesia. Diponegoro Journal of Accounting, 6(4): 216-25.

Keuangan, Otoritas Jasa. (2017). Perbankan Syariah Dan Kelembagaannya. https://www.ojk.go.id/id/kanal/syaria h/tentang-syariah/Pages/PBS-danKelembagaan.aspx.

Lestari, Santi. (2016). Pengaruh Tingkat Profitabilitas, Likuiditas, Leverage, Ukuran Perusahaan Dan Umur Perusahaan Terhadap Pengungkapan Islamic Social Reporting Pada Perbankan Syariah Indonesia Tahun 2010-2014. Jurnal Akuntansi Universitas Negeri Surabaya, 4(2): 1-24.

https://jurnalmahasiswa.unesa.ac.id/i ndex.php/jurnalakuntansi/article/view/14722.

Mais, Rimi Gusliana, and Nuning Lufian. (2018). Pengaruh Sharia Governance Structure Terhadap Pengungkapan CSR Berdasarkan Islamic Social Reporting Index. Jurnal Akuntansi Dan Manajemen, 15(1): 83-100.

Marimin, Agus, and Abdul Haris Romdhoni. (2017). PERKEMBANGAN BANK SYARIAH DI INDONESIA. Jurnal Ilmiah Ekonomi Islam, 1(02). https://doi.org/10.29040/jiei.v1i02.3.

Masrurroh, Dewi Ayou, and Ade Sofyan Mulazid. (2017). Return On Asset (Roa), Financing Deposit Ratio (Fdr) Terhadap Pengungkapan Corporate Social Responsibility (Csr) Bank Umum Syariah Di Indonesia Periode 2012-2015. Fakultas Ekonomi Dan
Bisnis, $\quad 4(1): \quad 1-18$. https://core.ac.uk/download/pdf/2669 76174.pdf.

Muchlis, Saiful, and Anna Sutrisna Sukirman. (2016). Implementasi Maqashid Syariah Dalam Corporate Social Responsibility Di Pt Bank Muamalat Indonesia. Jurnal Akuntansi Multiparadigma, 7(1). https://doi.org/10.18202/jamal.2016. 04.7011.

Muslihati, Muslihati, Siradjuddin Siradjuddin, and Syahruddin Syahruddin. (2018). Corporate Social Responsibility (CSR) Dalam Perspektif Ekonomi Islampada Bank Syariah." JURNAL HUKUM EKONOMI SYARIAH, 2(1): 29-42. https://doi.org/10.26618/jhes.v2i1.1390.

Mutia, Evi, Zuraida Zuraida, and Devi Andriani. (2011). Pengaruh Ukuran Perusahaan, Profitabilitas Dan Ukuran Dewan Komisaris Terhadap Pengungkapan Corporate Social Responsibility Pada Perusahaan Manufaktur Yang Terdaftar Di Bursa Efek Indonesia." Jurnal Telaah Dan Riset Akuntansi, 4(2): 187-201.

Nur Abdi Pratama, A., Saiful Muchlis, and Idra Wahyuni. (2018). Determinan Pengungkapan Islamic Social Reporting(Isr) Pada Perbankan Syariah Dengan Komisaris Independen Sebagai Variabel Moderating. Al-Mashrafiyah: Jurnal Ekonomi, Keuangan, Dan Perbankan Syariah, 1(2): 103-15. https://doi.org/10.24252/almashrafiyah.v1i2.4738.

Othman, Rohana, and Azlan Md Thani. (2010). Islamic Social Reporting Of Listed Companies In Malaysia. International Business \& Economics Research Journal (IBER), 9(4). https://doi.org/10.19030/iber.v9i4.56 1. 
Pare, Yormi Karto, Jullie J Sondakh, and Jenny Morasa. (2017). Pengaruh Karakteristik Perusahaan Terhadap Pengungkapan Corporate Social Responsibility Pada Perusahaan Perbankan Konvensional Di Indonesia. JURNAL RISET AKUNTANSI DAN AUDITING "GOODWILL, $8(2)$. https://doi.org/10.35800/jjs.v8i2.186 31.

Prasetyoningrum, Ari Kristin. (2019). Pengaruh Ukuran Perusahaan, Profitabilitas, Leverage, Efisiensi Biaya, Dan Umur Perusahaan Terhadap Islamic Social Reporting (ISR) Pada Perbankan Syariah Di Indonesia. MALIA: Journal of Islamic Banking and Finance, 2(2): 147. https://doi.org/10.21043/malia.v2i2.4 780.

Rahayu, Tantri Puji, and Agung Budi S. (2018). Analisis Faktor-Faktor Yang Mempengaruhi Pengungkapan Islamic Social Reporting Pada Perusahaan Yang Terdaftar Di Jakarta Islamic Index Periode 20102013. E-Journal Ekonomi Bisnis Dan Akuntansi, $\quad$ 5(2): 109. https://doi.org/10.19184/ejeba.v5i2.8 644.

Setyawan, Chandra Dwi. (2017). Pengaruh Dewan Komisaris Dan Investment Account Holders Terhadap Kinerja Bank Syariah Di Indonesia. Pengaruh Dewan Komisaris Dan Investment Account Holders Terhadap Kinerja Bank Syariah Di Indonesia, 6(3): 73-83.

Sudaryati, Dwi, and Yunita Eskadewi. (2012). Pengaruh Corporate Governance Terhadap Tingkat Pengungkapan Corporate Social Responsibility Di Bank Syariah. Jurnal Ekonomi Dan Bisnis, 11(1): 14-28.
Tampubolon, Entherthiman Galvani, and Dina Arfianti Siregar. (2019). Pengaruh Profitabilitas, Dan Ukuran Perusahaan Terhadap Pengungkpaan Tangging Jawab Sosial Pada Perusahaan Manufaktur Yang Terdaftar Di Bursa Efek Indonesia. Jurnal Maneksi, 8(2): 223-29.

Umiyati, Umiyati, and Muhammad Danis Baiquni. (2019). Ukuran Perusahaan, Profitabilitas, Dan Leverage Terhadap Islamic Social Reporting Pada Bank Umum Syariah Di Indonesia." Jurnal Akuntansi Dan Keuangan Islam, 6(1): 85-104. https://doi.org/10.35836/jakis.v6i1.1 0 .

Widiyanti, Novi Wulandari, and Nindya Tyas Hasanah. (2018). Analisis Determinan Pengungkapan Islamic Social Reporting (ISR) (Studi Kasus Pada Perusahaan Yang Terdaftar Pada Jakarta Islamic Index Tahun 2011 - 2015). BISNIS : Jurnal Bisnis Dan Manajemen Islam, 5(2): 239. https://doi.org/10.21043/bisnis.v5i2. 3013.

Zanjabil, Aviciena, and Adityawarman. (2015). Faktor-Faktor Yang Mempengaruhi Pengungkapan CSR (Corporate Social Responsibility) Pada Perbankan Syariah Di Indonesia. Diponegoro Journal of Accounting, 4(3): 1-13. 